\title{
A review of zinc nutrition and plant breeding
}

\author{
B. Sadeghzadeh ${ }^{1,2}$ \\ ${ }^{1}$ Soil Science and Plant Nutrition, Faculty of Natural and Agricultural Sciences, University of Western Australia, Crawley WA \\ 6009, Australia. ${ }^{2}$ Dryland Agricultural Research Institute (DARI), Maragheh, Iran. Corresponding author: Behzada4@yahoo.com
}

\begin{abstract}
Plants require the proper balance of zinc $(\mathrm{Zn})$ for normal growth and optimum yield. Interest in $\mathrm{Zn}$ has risen in the last decade because $\mathrm{Zn}$ deficiency stress is extensive in many areas, causing decreases in crop yields. $\mathrm{Zn}$ deficiency also decreases the amount of $\mathrm{Zn}$ in cereal grain and diminishes its nutritional quality. Hence, increasing the $\mathrm{Zn}$ content of the edible portions of crops should be considered in plant breeding. Available data indicate that $\mathrm{Zn}$ enrichment traits are present within the genomes of crops that could allow for substantial increases in the $\mathrm{Zn}$ concentration of edible parts without negatively impacting yield. Increasing the amount of $\mathrm{Zn}$ in food crops can improve the $\mathrm{Zn}$ status of people. Furthermore, the use of $\mathrm{Zn}$-dense seeds results in greater seedling vigor and increased crop yields when the seeds are sown in $\mathrm{Zn}$-poor soils. Progress toward developing mineral-dense seed has mainly relied upon conventional plant breeding approaches, a process that is labor-intensive and time-consuming. Hence, the identification of DNA markers that are diagnostic of Zn efficiency can accelerate the development of cultivars that can remain productive even in Zn-deficient soils. Additionally, these markers may be used to begin identifying the specific genes responsible for differences in the response of genotypes to $\mathrm{Zn}$ deficiency.
\end{abstract}

Keywords: Zinc deficiency, genotypic variation, breeding, olecular markers

\section{Introduction}

Zinc ( $\mathrm{Zn}$ ) deficiency is the most widespread micronutrient deficiency in agricultural lands around the world, causing yield decreases and diminishing the nutritional quality of agricultural plants. $\mathrm{Zn}$ is important for plant growth, as plants require a proper balance of all the essential nutrients for normal growth and optimum yield. Plant-based foods are significant sources of $\mathrm{Zn}$ for humans (Welch and Graham, 2004).

Zinc is one of the eight trace elements (manganese, copper, boron, iron, zinc, chlorine, molybdenum and nickel) that are essential for normal, healthy growth and reproduction of plants. $\mathrm{Zn}$ is required as a structural component of a large number of proteins, such as transcription factors and metalloenzymes (Figueiredo et al., 2012). If an insufficient amount of $\mathrm{Zn}$ is available, the plants will suffer from physiological stresses due to the failure of metabolic processes in which $\mathrm{Zn}$ plays a critical role. Zinc in soils can be separated into fractions based on particle size distribution and/or chemical analysis procedures. 
The amount of $\mathrm{Zn}$ in each of the chemical pools or forms differs due to the range of $\mathrm{Zn}$ concentrations found in the soil parent material and the extent of weathering. $\mathrm{Zn}^{2+}$ is released from many primary minerals into the soil solution during rock weathering. The total $\mathrm{Zn}$ concentration of soils is related to the composition of the parent rock material and soil mineralogy. In the soil, $\mathrm{Zn}$ forms complexes with organic acids, humic substances and other types of dissolved organic carbon. The total $\mathrm{Zn}$ concentration is not used for evaluating the availability of soil $\mathrm{Zn}$ to the plants because only a small amount of total $\mathrm{Zn}$ is exchangeable or soluble. The availability of $\mathrm{Zn}$ to plants depends on several soil factors such as the concentration of $\mathrm{Zn}$ in solution, ion speciation and the interaction of $\mathrm{Zn}$ with other macronutrients and micronutrients (Li et al., 2003).

Zinc deficiency may cause large reductions in crop quality and yield. Wheat and barley show significant decreases in growth and grain yield under Zn-deficient conditions in the field (Graham et al., 1992; McDonald et al., 2001). Zn deficiency in soils also reduces $\mathrm{Zn}$ concentration and content in the edible portions of staple food crops and diminishes their nutritional quality (Welch and Graham, 2004). Approximately $40 \%$ of world's population suffers from micronutrient deficiencies (the so-called "hidden hunger"), including $\mathrm{Zn}$ deficiency. The World Health Organization estimates that $\mathrm{Zn}$ deficiency affects one-third of the world's population (approximately two billion people), with prevalence rates ranging from 4 to $73 \%$ in various regions (WHO, 2002). A diet consisting of a high proportion of cereal-based foods with low $\mathrm{Zn}$ content is considered one of the major reasons for the widespread occurrence of $\mathrm{Zn}$ deficiency in humans, especially in developing countries (Biesalski, 2013).

Visible Zn deficiency symptoms in crops usually occur only in cases of relatively severe deficiency. In marginal deficiency, crop quality and yield may be reduced because of hidden $\mathrm{Zn}$ deficiency without obvious symptoms (Alloway, 2004). This hidden Zn deficiency may go undetected for several seasons at a high cost to farmers. Most soils with low plant-available $\mathrm{Zn}$ can be treated with $\mathrm{Zn}$ fertilizers to correct crop $\mathrm{Zn}$ deficiency. Several different $\mathrm{Zn}$ sources, including $\mathrm{ZnSO}_{4}, \mathrm{ZnCO}_{3}$, $\mathrm{ZnO}, \mathrm{Zn}\left(\mathrm{NO}_{3}\right)_{2}$ and $\mathrm{ZnCl}_{2}$, are currently being used as fertilizers.

When fertilizers are applied to correct $\mathrm{Zn}$ deficiency, the added $\mathrm{Zn}$ is likely to remain near the surface, even in sandy textured soils. In semi-arid areas, applying liquid forms of nitrogen, phosphate and $\mathrm{Zn}$ fertilizers to the subsoil (up to $40 \mathrm{~cm}$ deep) can better increase crop $\mathrm{Zn}$ uptake and grain yield compared with the application of granular fertilizers to the surface. Moreover, $\mathrm{Zn}$ fertilizers may be unavailable or unaffordable in developing countries. Because of the widespread $\mathrm{Zn}$ deficiency problems and difficulties in alleviating this deficiency with fertilizers, the development of crops that are efficient $\mathrm{Zn}$ accumulators, especially under low soil $\mathrm{Zn}$ conditions, is an important approach for improving $\mathrm{Zn}$ deficiency tolerance, grain productivity and micronutrient quality. In addition, Zn-efficient genotypes could reduce land degradation by limiting the use of machinery and minimizing fertilizer inputs on agricultural lands. Zn-efficient cultivars of wheat, barley and rice are available (Gregorio et al., 2000; Genc and McDonald, 2004) and are grown quite widely in soils with low levels of available $\mathrm{Zn}$.

Plant genotypes vary widely in their tolerance to soils with low plant-available $\mathrm{Zn}$ with respect to both $\mathrm{Zn}$ uptake and utilization. Tolerance of plant genotypes to $\mathrm{Zn}$ deficiency, as a genetic trait, is usually referred to as $\mathrm{Zn}$ efficiency and defined as the ability of a cultivar to grow and yield well in soils that are too deficient in $\mathrm{Zn}$ to support a standard cultivar. The physiological and molecular mechanisms of $\mathrm{Zn}$ deficiency tolerance are just beginning to be understood, and these mechanisms can be exploited in crop breeding programs (Hacisalihoglu and Kochian, 2003) For example, $\mathrm{Zn}$-efficient genotypes with better $\mathrm{Zn}$ utilization may contain higher amounts of chelators that bind $\mathrm{Zn}$ and increase its physiological availability at the cellular level. A better understanding of the physiological, morphological and genetic bases of $\mathrm{Zn}$ efficiency is 
needed for the development of fast, simple and reliable screening procedures for identifying and breeding genotypes for $\mathrm{Zn}$ efficiency. The first step in breeding for $\mathrm{Zn}$ efficiency is the assessment of a large number of segregating populations from crosses of $\mathrm{Zn}$-efficient $\times$ Zn-inefficient parents.

Field and pot screening studies have revealed significant genetic variation in Zn efficiency in cereal genotypes, which indicates that selection for improved $\mathrm{Zn}$ efficiency is possible. Pot screening is common, being less expensive and faster than fieldwork. In addition, the problem of soil heterogeneity can be eliminated by screening in pots. However, root binding in small pots may be an independent limiting factor, which can obscure a comprehensive view of $\mathrm{Zn}$ efficiency. Moreover, the environment is less realistic in glasshouse experiments than in the field.

In the near future, it is anticipated that molecular techniques will dominate screening for $\mathrm{Zn}$ efficiency and many other desired traits. In particular, the use of DNA markers for these traits could permit the selection of improved crop cultivars. An increasing number of genetic maps allow traits to be mapped to a particular chromosome, thereby allowing the selection of flanking DNA markers and obviating the need for time-consuming and expensive bioassays.

Over the past two decades, molecular tools have aided the identification, mapping and isolation of genes in a wide range of crop species. Molecular markers have been used for the development of detailed genetic and physical chromosome maps in crops. Another major use of molecular markers in plant systems involves improving the efficiency of conventional plant breeding by indirect selection, which is accomplished using molecular markers linked to qualitative and quantitative trait loci (QTLs). Molecular marker applications have also increased our understanding of the physiological parameters controlling plant responses to biotic and abiotic stress. The main advantages of molecular markers are that they are available for many traits, are not affected by the environment and can be scored at virtually any stage of plant development.

Progress has been made toward identifying Mnand $\mathrm{Zn}$-efficient parents in wheat and barley and in developing genotypes that are more efficient. However, the variability inherent in field screening has produced some inconsistent results. This issue may be overcome by the use of molecular marker technology, which allows the traits for nutrient efficiency to be selected directly. Molecular markers for micronutrient efficiency (e.g., Mn and $\mathrm{Zn}$ ) have been identified in barley (Pallotta et al., 2000; Lonergan et al., 2001; Sadeghzadeh, 2008; Sadeghzadeh et al., 2009), bread wheat (Xu et al., 2012), durum wheat (Khabaz-Saberi et al., 2002) and maize (Qin et al., 2012). This review will first cover $\mathrm{Zn}$ deficiency in soils followed by $\mathrm{Zn}$ deficiency in plants. Subsequently, breeding for $\mathrm{Zn}$ efficiency will be addressed, followed by application of molecular markers in Zn efficiency.

\section{Zinc deficiency}

When the supply of $\mathrm{Zn}$ to plants is inadequate (i.e., there is deficiency of $\mathrm{Zn}$ ), one or more of many important physiological functions that depend on $\mathrm{Zn}$ are impaired, and plant growth is adversely affected. The necessity of $\mathrm{Zn}$ for normal growth has only been scientifically recognized for approximately 70 years (Alloway, 2004), and in some areas of the world, the existence of $\mathrm{Zn}$ deficiency has only been acknowledged in recent years. $\mathrm{Zn}$ deficiency is a severe micronutrient deficiency that threatens world food production (Alloway, 2001; Welch and Graham, 2004). Therefore, understanding and knowledge of Zn deficiency would facilitate the appropriate management of this problem.

Recently, reports of Zn deficiency in various crops have increased because high-yielding plant varieties and intensive cultivation remove large amounts of $\mathrm{Zn}$ from the soil at every harvest. Many new breeds and varieties are much more susceptible to $\mathrm{Zn}$ deficiency than locally adapted crop genotypes. The increased use of phosphorus $(\mathrm{P})$ fertilizers as well as fertilizers 
with less Zn-containing impurities can exacerbate Zn deficiency (Loneragan and Webb, 1993). In SubSaharan Africa, the Near East/North Africa and South Asia, the food supply has kept up with population growth. However, simply consuming enough calories has resulted in unforeseen nutritional problems for people, especially those who are poor. Hence, increasing the $\mathrm{Zn}$ content of staple crops will enhance the intake of bioavailable $\mathrm{Zn}$ and improve the $\mathrm{Zn}$ status of deficient populations (Biesalski, 2013).

Briefly, the main causes of $\mathrm{Zn}$ deficiency in crops are low $\mathrm{Zn}$ availability (high $\mathrm{pH}$, calcareous and sodic soils), low total soil $\mathrm{Zn}$ concentration (especially in sandy, sodic and calcareous soils), high levels of nitrogen and phosphate and restricted root exploration due to soil compaction or a high water table, particularly in soils with a marginal Zn status (Alloway, 2004).

\section{Zinc in soils}

\section{Distribution of zinc deficiency}

Zinc deficiency occurs in a wide range of soil types in many parts of the world; however, tropical regions with highly weathered soils, semi-arid areas with calcareous high-pH soils, sandy-textured soils, and acid soils in several different climatic zones tend to be the most seriously affected because of their low $\mathrm{Zn}$ content. The results of 190 field trials in 15 countries around the world showed that $\mathrm{Zn}$ deficiency was the most frequently occurring micronutrient deficiency. Zn deficiency was recorded in $49 \%$ of the trials, with acute forms (with visible symptoms) noted in $25 \%$ and hidden deficiencies confirmed by yield responses to $\mathrm{Zn}$ amendments noted in 24\% (Sillanpää, 1990).

It is estimated that approximately $50 \%$ of soils used for cereal production in the world have low levels of plantavailable $\mathrm{Zn}$ (Graham and Welch, 1996). Low levels of plant-available $\mathrm{Zn}$ have been reported in the arid and semi-arid regions of India, paddy fields of Pakistan, poorly drained calcareous paddy soils of China and highly alkaline soils with low levels of organic matter in Central Anatolia of Turkey. In Australia, soils with low plant-available $\mathrm{Zn}$ are found in southern Australia, Victoria, Queensland, New South Wales and Western Australia. Southwest Australia is considered the largest continuous Zn-deficient area in the world. Such largescale deficiencies have made Australia a world center of research on micronutrient problems.

\section{Zinc uptake from soil}

Zinc enters plants primarily via root absorption of Zn2+ from the soil solution, which is a dynamic and complex process. Uptake depends on ion concentrations at the root surface, plant demand and root absorption capacity. $\mathrm{Zn}$ reaches the plant root surface through mass flow, diffusion and root interception mechanisms.

Mass flow is passive nutrient transport from the soil to the roots and is driven by transpiration. When the solution moving through the soil to the root contains a relatively large concentration of $\mathrm{Zn}$, mass flow becomes the dominant mechanism bringing $\mathrm{Zn}$ to the root surface.

When the $\mathrm{Zn}$ concentration is low, particularly in soils with low plant-available $\mathrm{Zn}$, diffusion plays important role in the transport of $\mathrm{Zn}$ and other nutrients, such as $\mathrm{P}, \mathrm{K}, \mathrm{Cu}, \mathrm{Fe}$ and $\mathrm{Mn}$, to the root surface because mass flow can only carry a small fraction of the nutrients required by the plants. In contrast to mass flow, diffusion operates only in the immediate volume of soil surrounding a root.

The interception of nutrients by roots is an important uptake mechanism for soil immobile nutrients such as $\mathrm{Zn}$. Thus, root interception (i.e., root growth and root surface area) is also an important factor in determining plant availability of $\mathrm{Zn}$. Poor root interception can limit $\mathrm{Zn}$ uptake if granules of $\mathrm{ZnSO}_{4}$ are banded in the soil, particularly at a low rate of $\mathrm{ZnSO}_{4}$ application.

\section{Factors affecting the availability of soil zinc to plants}

The term "availability" is commonly used to describe the ability of plants to take up nutrients from the soil. 
Several authors have extensively reviewed the factors affecting the solubility of $\mathrm{Zn}$ in soils and its availability to plants. $\mathrm{Zn}$ availability to plants can be affected by factors such as total soil $\mathrm{Zn}$ content, soil $\mathrm{pH}$, organic matter, soil temperature and moisture regimes, root distribution and rhizosphere effects.

Soils with a low total $\mathrm{Zn}$ concentration are often $\mathrm{Zn}$ deficient for crop production. Sandy soils, frequently deficient in available $\mathrm{Zn}$, have an inherently low total $\mathrm{Zn}$ concentration. For example, $\mathrm{Zn}$ deficiency in plants grown on acid soils is generally associated with a low total soil $\mathrm{Zn}$ concentration. These cases of $Z n$ deficiency are related to an absolute $Z n$ deficiency rather than $\mathrm{Zn}$ availability.

With the exception of molybdenum, the availability of micronutrients generally decreases as the soil $\mathrm{pH}$ increases. Increasing the soil $\mathrm{pH}$ stimulates $\mathrm{Zn}$ adsorption to the surface of various soil constituents, such as metal oxides and clay minerals; this results in decreases in the solubility and availability of $\mathrm{Zn}$ to plants. A high $\mathrm{pH}$ decreases the desorption of $\mathrm{Zn}$ from soil surfaces, which also reduces the availability of $\mathrm{Zn}$ to plants. $\mathrm{Zn}$ can precipitate in the form of $\mathrm{Zn}(\mathrm{OH})_{2}$, $\mathrm{ZnCO}_{3}$ and $\mathrm{Zn}_{2} \mathrm{SiO}_{4}$ at high $\mathrm{pH}$. The $\mathrm{Zn}$ concentration in the soil solution is largely dependent on $\mathrm{pH}$; for example, at $\mathrm{pH} 5.0$, the concentration of $\mathrm{Zn}$ in the soil solution is approximately $10-4 \mathrm{M}$, whereas at $\mathrm{pH}$ 8.0 , this concentration is $10-10 \mathrm{M}$. Liming of acid soils resulted in an increase in the soil $\mathrm{pH}$ from 5.2 to 6.8 and an approximate 10-fold decrease in the $\mathrm{Zn}$ concentration in plants (Parker and Walker, 1986).

In acid soils, in contrast, the availability of $\mathrm{Zn}$ depends on the amount of soil $\mathrm{Zn}$. In sandy loam, the availability of natural and supplied $\mathrm{Zn}$ doubled when the soil $\mathrm{pH}$ was reduced from 7 to 5 using ammonium sulfate.

The total soil $\mathrm{Zn}$ concentration in calcareous and noncalcareous soils is often similar; however, $\mathrm{Zn}$ deficiency is frequently reported for calcareous soils (Singh et al., 2005). Calcareous soils ( $\mathrm{pH}>7$ ) with moderate-to-high organic matter content ( $>15 \mathrm{~g}$ organic $\mathrm{C}$ per kg soil) are likely to be $\mathrm{Zn}$-deficient due to high levels of $\mathrm{HCO}_{3}{ }^{-}$in the soil solution (Singh et al., 2005) In alkaline soils with a low Zn supply, increasing the Zn application increased the $\mathrm{Zn}$ concentration in plants and reduced the deficiency symptoms; however, plant growth was only slightly improved. It was concluded that plant growth on the alkaline soil was more responsive to soil alkalinity than $\mathrm{Zn}$ deficiency.

Soil organic matter content is another factor that contributes to $\mathrm{Zn}$ deficiency in crops. Zn availability to plants is often reported to be low in soils with high organic matter content due to increased adsorption of $\mathrm{Zn}$ by organic ligands and components. An adequate level of organic matter increases the solubility and diffusion rate of $\mathrm{Zn}$ in soils. In the United States, Zn deficiency problems frequently occur in areas where the surface soil has been removed by land leveling (Alloway, 2004). The underlying soil has less organic matter than the topsoil, and in many cases, the subsoil also has a higher $\mathrm{pH}$. Several researchers have shown a positive correlation between extractable $\mathrm{Zn}$ and organic matter. Both the diethyltriamine pentaacetic acid (DTPA)extractable $\mathrm{Zn}$ and organic matter content decrease with depth in the soil profile (Alloway, 2004). An experiment in wheat showed that the $\mathrm{Zn}$ content is positively correlated with the level of soil organic matter.

Other factors that contribute to $\mathrm{Zn}$ deficiency include low soil moisture and low temperature (Moraghan and Mascagni Jr, 1991). Soil moisture affects the nutrient supply by impairing diffusion to the root surface. Given that $\mathrm{Zn}$ diffusion in soils is highly dependent on soil moisture, plant $\mathrm{Zn}$ nutrition may be at risk in semiarid and arid areas where soils are usually water-deficient for long periods during the growing season. Accordingly, in Zn-deficient calcareous soils, wheat yield reductions are more severe under rainfed versus irrigated conditions. However, waterlogging alters $\mathrm{Zn}$ chemistry in the soil; for example, submerged soils have decreased concentrations of water-soluble $\mathrm{Zn}$ compared with well-drained soils. In addition, decreased $\mathrm{Zn}$ solubility and low $\mathrm{Zn}$ uptake in poorly drained soils is due to the co- 
precipitation of $\mathrm{Zn}$ with soluble iron and aluminum in the soil. Early in the growing season, $\mathrm{Zn}$ deficiency occurs when the soil temperature is still relatively low and subsequently diminishes as the temperature rises. A low soil temperature often increases the incidence and severity of $\mathrm{Zn}$ deficiency symptoms (Moraghan and Mascagni Jr, 1991). It was suggested that a colder root zone temperature decreases root colonization with vesicular-arbuscular (VA) mycorrhizae, root growth, $\mathrm{Zn}$ uptake and $\mathrm{Zn}$ translocation into the shoots (Schwartz et al., 1987; Moraghan and Mascagni Jr, 1991). In barley, shoot $\mathrm{Zn}$ uptake was $82 \%$ higher in plants grown in solution at $20^{\circ} \mathrm{C}$ compared with those grown at $10^{\circ} \mathrm{C}$ (Schwartz et al., 1987).

Soil analysis can be used as a tool for predicting nutrient deficiency in existing crops, and it is also more valuable for predicting deficiencies and corrective actions that can be taken to avoid yield losses in subsequent crops. The critical soil levels that lead to $\mathrm{Zn}$ deficiency vary between 0.6 and $2.0 \mathrm{mg} \mathrm{Zn} / \mathrm{kg}$ soil depending on the $\mathrm{Zn}$ extraction method (Singh et al., 2005). Several soil analytical procedures are available for predicting $\mathrm{Zn}$ availability in soils, including extractions with chelating agents, such as DTPA and ethylenediamine tetraacetic acid (EDTA), and salts, such as ammonium acetate. The DTPA method is widely used for predicting plant-available $\mathrm{Zn}$ in soils. Based on greenhouse and field experiments, approximately $0.6 \mathrm{mg} / \mathrm{kg}$ DTPA-extractable $\mathrm{Zn}$ has been suggested as a critical concentration for wheat grown in calcareous soils of arid regions in India. In Australia, the critical DTPA-extractable $\mathrm{Zn}$ concentration in acidic soils is $0.25 \mathrm{mg} / \mathrm{kg}$ for wheat.

Soils with low plant-available $\mathrm{Zn}$ can be treated with $\mathrm{Zn}$ fertilizers to provide an adequate supply of $\mathrm{Zn}$ to crops. Several different $\mathrm{Zn}$ compounds are used as fertilizers; although $\mathrm{ZnSO}_{4}$ is by far the most widely used material. $\mathrm{ZnSO}_{4}$ can also be used as a foliar treatment for crops; however, chelated forms of $\mathrm{Zn}$ are usually used for foliar application (Alloway, 2001). The application rates of $\mathrm{Zn}$ fertilizers will also vary depending on the crop, the form of $\mathrm{Zn}$ applied, the soil conditions and the application method. For soil applications, concentrations can range from $2.5-22 \mathrm{~kg}$ $\mathrm{Zn} / \mathrm{ha}$ for inorganic forms, such as $\mathrm{ZnSO}_{4}$, and 0.3-6 $\mathrm{kg} \mathrm{Zn/ha} \mathrm{for} \mathrm{chelated} \mathrm{forms} \mathrm{(Alloway,} \mathrm{2001).}$

Finally, the interaction of $\mathrm{Zn}$ with other elements decreases $\mathrm{Zn}$ availability and influences its adsorption, distribution and utilization in plants. These interactions are mainly due to the influences of other cations on the rate of absorption by plant roots rather than to their effects on the availability of $\mathrm{Zn}$ or its forms (Loneragan and Webb, 1993). Zn interactions with $P$ and nitrogen $(\mathrm{N})$ are the most important and widespread in soils with limiting supplies of $\mathrm{Zn}$ and $\mathrm{P}$ or $\mathrm{N}$. A high level of applied $\mathrm{N}$ in the absence of $\mathrm{Zn}$ can cause $\mathrm{Zn}$ deficiency through a dilution effect, changing the $\mathrm{pH}$ of the root environment (Loneragan and Webb, 1993) and increasing the shoot-to-root ratio (Loneragan and Webb, 1993).High levels of $\mathrm{P}$ in the soil can also occasionally increase the symptoms of $\mathrm{Zn}$ deficiency. $\mathrm{Zn}$ and $\mathrm{P}$ co-precipitation in the soil may cause the formation of insoluble $\mathrm{ZnO}_{3}\left(\mathrm{PO}_{42}\right.$, whichdecreases the $\mathrm{Zn}$ concentration of the soil solution and thus lowers $\mathrm{Zn}$ availability. Moreover, under limiting or marginal supplies of $\mathrm{Zn}$ and $\mathrm{P}$, the application of $\mathrm{P}$ causes $\mathrm{Zn}$ deficiency due to the dilution of the plant $\mathrm{Zn}$ concentration as a result of growth stimulation. Yang et al. (2011) reported that with increasing $\mathrm{P}$ application, the proportion of $\mathrm{Zn}$ and $\mathrm{P}$ content in the grain relative to the whole plant decreased. Moreover, $\mathrm{P}$ and $\mathrm{Zn}$ acted antagonistically in roots; and excess $\mathrm{P}$ inhibited $\mathrm{Zn}$ uptake in roots.

\section{Zinc in plants}

\section{The functions of zinc in plants}

Zinc is essential for the normal, healthy growth and reproduction of plants. This element is required in small amounts to allow the normal function of several key plant physiological pathways as well as to ensure the structural and functional integrity of membranes. Thus, $\mathrm{Zn}$ has important roles in growth regulation, enzyme activation, gene expression 
and regulation, phytohormone activity, protein synthesis, photosynthesis, carbohydrate metabolism, fertility, seed production and defense against disease (Marschner, 1995). Zn deficiency will impair these physiological functions and compromise the health and productivity of plants, leading to severe reduction in growth, lower yields (or even crop failure) and poor quality crop products.

Zinc is the only metal that is required in all six enzyme classes (oxidoreductases, transferases, hydrolases, lyases, isomerases and ligases). The requirement of $\mathrm{Zn}$ for the function of a wide range of enzymes indicates that the metabolism of proteins, carbohydrates and auxin as well as reproductive processes are hampered under Zn deficiency (Römheld and Marschner, 1991). $\mathrm{Zn}$ is required for the activity of metalloenzymes that are involved in protein and nucleic acid metabolism.

Zinc is involved in carbohydrate metabolism via its effects on photosynthesis and sugar transformation. Reduced photosynthesis under $\mathrm{Zn}$ deficiency can result from a decrease in carbonic anhydrase (CA) activity, the photochemical activity of chloroplasts and chlorophyll content, as well as alterations in chloroplast structure. Low CA may inhibit photosynthetic electron transfer and consequently limit chlorophyll content (Römheld and Marschner, 1991).

Zinc is essential in protein metabolism, and the most important role of $\mathrm{Zn}$ in protein synthesis is its involvement in the stability and function of genetic material. $\mathrm{Zn}$ is essential in chromatin structure, DNA/RNA metabolism and gene expression. Zn deficiency causes a decrease in protein synthesis (Marschner, 1995) due to RNA degradation (Cakmak et al., 1989), decreased activity of RNA polymerase, ribosomal deformation and a decrease in the number of ribosomes. In $\mathrm{Zn}$-deficient bean leaves, the free amino acid concentration was increased by a factor of 6.5 compared with that of control plants. Upon resupply of $\mathrm{Zn}$, this factor decreased to 5.1 after 24 h, 2.7 after $48 \mathrm{~h}$ and 1.4 after $72 \mathrm{~h}$ (Cakmak et al., 1989).
Zinc has an important physiological role in maintaining the integrity and function of cellular membranes by controlling the generation and detoxification of reactive oxygen species. Reactive oxygen species are potentially damaging to membrane lipids and sulfhydryl groups. When these compounds are damaged due to oxidative stress, there is increased leakage of several organic compounds, such as carbohydrates and amino acids, from $\mathrm{Zn}$-deficient root cells. Due to the increased leakage of carbon-containing compounds into the rhizosphere, Zn-deficient plants may be susceptible to root diseases such as Fusarium graminearum.

\section{Zinc uptake and movement in plants}

Roots take up $\mathrm{Zn}$ from the soil solution as a divalent cation $\left(\mathrm{Zn}^{2+}\right)$, and at high $\mathrm{pH}, \mathrm{Zn}$ is absorbed as a monovalent $\left(\mathrm{ZnOH}^{+}\right)$cation (Marschner, 1995). $\mathrm{Zn}$ accumulation in plant roots exhibits biphasic kinetics, with initial rapid entry and binding within the root cell wall followed by a slower linear transport phase across the plasma membrane. $\mathrm{Zn}^{2+}$ movement from the external solution to the root cell wall free space occurs via diffusion, and $\mathrm{Zn}$ is subsequently transported across the plasma membrane via ion transport proteins. The cytoplasm of a plant cell is negatively charged, and there is an electrical gradient that draws cations, including $\mathrm{Zn}^{2+}$, into the cell. Reid et al. (1996) reported that it appears unnecessary to invoke an active transport system for $\mathrm{Zn}$ transport across the plasma membrane because a $\mathrm{Zn}$ influx will be thermodynamically favored. Root $\mathrm{Zn}$ uptake is mediated by different transport systems: a high-velocity, low-affinity membrane transporter system $\left(\mathrm{K}_{\mathrm{m}}=2-5\right.$ $\mu \mathrm{M})$ and a low-velocity, high affinity system $\left(\mathrm{K}_{\mathrm{m}}=0.6-2\right.$ $\mathrm{nM}$ ), which is most likely the dominant transport system under low soil $\mathrm{Zn}$ conditions (Hacisalihoglu et al., 2001). Generally, Zn-inefficient plants have lower rates of uptake and comparable affinity values compared with $\mathrm{Zn}$ efficient plants (Rengel and Wheal, 1997; Hacisalihoglu et al., 2001).

From the root surface, nutrients are transported into the root xylem through the epidermis, cortex and endodermis (Marschner, 1995). Zn may pass through 
the root to the xylem either through the extracellular spaces between root cells (apoplast) (White et al., 2002) or through the cytoplasmic continuum of root cells linked by plasmodesmata (symplast). The apoplastic cation flux is largely determined by the cation exchange properties of the cell wall, water flows and the existence of Casparian band. Given that the symplastic pathway involves specific transporters in the plasma membrane, particular cations can be selected for transport (Sattelmacher, 2001). In Thlaspi caerulescens and $T$. arvense, the entry point for $\mathrm{Zn}$ accumulation is across the plasma membrane of root cells, and $\mathrm{Zn}$ reaches the xylem via the symplastic pathway in both species (Lasat et al., 1996; Lasat and Kochian, 2000). With an increasing external Zn concentration, the apoplastic pathway plays a greater role in $\mathrm{Zn}$ uptake and influx to the xylem (White et al., 2002).

Nutrients in the xylem move toward shoots in the transpiration stream. This driving force for transpiration arises from the gradient in water potential between stomatal cells and the atmosphere. An analysis of xylem fluid content showed that $\mathrm{Zn}$ moves as a complexed form (e.g., anionic) in the xylem. $\mathrm{Zn}$ in the xylem has been measured in a soluble form bound to small proteins and as insoluble complexes, such as Zn-phytate. Metal complexes and ionic activities of micronutrients differ in the xylem and phloem saps (Welch, 1995). The activity of cationic micronutrients, such as $\mathrm{Mn}, \mathrm{Zn}, \mathrm{Fe}, \mathrm{Cu}$ and $\mathrm{Ni}$, is low in the phloem sap due to a high phosphate level and high $\mathrm{pH}$. Hence, these micronutrients are likely to form metal complexes to move easily in the phloem stream (Welch, 1995).

\section{Zinc deficiency in plants}

Many plant species are affected by Zn deficiency in a wide range of soil types in most agricultural regions of the world. The major staple crops (rice, wheat, barley, maize and sorghum) are all affected by Zn deficiency, together with many different fruits, vegetables and other types of crops, including cotton and flax. Low soil concentrations of plant-available $\mathrm{Zn}$ may cause not only a decrease in grain yield but also lead to poor nutritional quality of crop products (Graham and Welch, 1996). However, more severe deficiencies (with leaf symptoms) can reduce yield severely and even result in crop failure.

Zinc deficiency can impair many biochemical pathways in crops, which may manifest in visible symptoms such as small and distorted leaves, interveinal chlorosis in young leaves and shortened internodes (Marschner, 1995). In barley, the visual Zn deficiency symptoms include stunted plants and leaves, chlorotic areas on leaves, necrosis, white spots on leaves and mid-leaf collapse (Genc et al., 2003; Lombnaes and Singh, 2003). In wheat, the symptoms of $\mathrm{Zn}$ deficiency are usually observed in young seedlings; later, whitishbrown patches and necrotic lesions can be observed on the leaf blades along with mid-leaf collapse (Rengel and Graham, 1995b; Cakmak and Braun, 2001). The appearance of these symptoms can vary with environmental conditions, plant age, deficiency stage and severity as well as the supply of other nutrients.

The $\mathrm{Zn}$ efficiency of genotypes can be determined based on phenotypic characteristics such as the severity of visible deficiency symptoms on leaves. The visual symptoms of $\mathrm{Zn}$ deficiency vary considerably between barley genotypes and are significantly correlated with Zn efficiency and grain yield (Genc et al., 2002b).

Within all crop species, individual varieties (or cultivars) can often vary considerably in their susceptibility to $\mathrm{Zn}$ deficiency. It is therefore important to screen crop varieties such that the more tolerant (or $\mathrm{Zn}$-efficient) varieties can be grown on soils with low plant-available $\mathrm{Zn}$. Genotypes can be screened for $\mathrm{Zn}$ efficiency based on the expression and severity of visible Zn-deficiency symptoms on leaves. Using a visual score of deficiency symptoms in barley, it was found that a single gene controls increased tolerance to $\mathrm{Zn}$ deficiency in a $\mathrm{Zn}$ efficient genotype compared with a $\mathrm{Zn}$-inefficient genotype at the seedling stage. Hence, visual $\mathrm{Zn}$ deficiency scores are useful for genetic analysis of tolerance to Zn deficiency (Genc et al., 2003). 
The critical (or threshold) concentration (usually defined as $90 \%$ of maximum yield) of $\mathrm{Zn}$ in tissues varies with plant species, cultivar, plant age, plant part and the environment. Whole shoots, roots, young leaves and grains are used for diagnosing $\mathrm{Zn}$ status. Leaves have been considered the most appropriate plant parts to sample for determination of the nutrient status. The critical $\mathrm{Zn}$ concentrations in leaves vary between $20 \mathrm{mg} \mathrm{Zn} / \mathrm{kg}$ in wheat, $15 \mathrm{mg} \mathrm{Zn/kg}$ in rice and $22 \mathrm{mg} \mathrm{Zn} / \mathrm{kg}$ in maize and groundnut. In whole young plants, the reported values are $8 \mathrm{mg} \mathrm{Zn} / \mathrm{kg}$ for sorghum, $22 \mathrm{mg} \mathrm{Zn/kg}$ for rice and $25 \mathrm{mg} \mathrm{Zn} /$ $\mathrm{kg}$ for wheat and chickpea. However, differences can also occur between different varieties of these crops (Alloway, 2001).

It has been suggested that biochemical analysis can be an excellent indicator of nutrient status, particularly when plant tissues contain a large amount of physiologically inactive nutrients. The activity of carbonic anhydrase was used to diagnose $\mathrm{Zn}$ deficiency in wheat (Rengel, 1995), mustard (Chatterjee and Khurana, 2007) and maize. Additionally, the activity of aldolase and ribonuclease appear to be reliable biological indicators of the $\mathrm{Zn}$ status of mustard (Chatterjee and Khurana, 2007).

Zinc deficiency in crop production can be ameliorated through agronomy and/or genetic improvement. Substantial crop responses to $\mathrm{Zn}$ fertilization were reported in Australia, India and especially in Central Anatolia (Turkey), where wheat grain yields have increased by over $600 \%$ since the mid- 1990 s (Cakmak, 2004). An alternative approach to increasing crop yields in soils with low plant-available $\mathrm{Zn}$ involves exploiting genotypic differences in $\mathrm{Zn}$ uptake and tissue-use efficiency that exist within crop species (Rengel, 2001; Hacisalihoglu and Kochian, 2003; Alloway, 2004). This approach involves matching the plant to the soil rather than modifying the soil to suit the plant. There are $\mathrm{Zn}$-efficient cultivars of rice, wheat and other crops that are grown widely in soils with low concentrations of plant-available $\mathrm{Zn}$.

\section{Mechanisms of $\mathrm{Zn}$ efficiency in plants}

Various mechanisms have been proposed to explain $\mathrm{Zn}$ efficiency at the molecular, physiological, structural and developmental levels in Zn-efficient genotypes; however, the actual mechanisms involved in $\mathrm{Zn}$ efficiency are not clear. In general, Zn-efficient genotypes exhibit increased Zn uptake efficiency at the roots and/ or more efficient utilization of $\mathrm{Zn}$ within the cells. It was suggested that $\mathrm{Zn}$-efficient plant species have the ability to mine $\mathrm{Zn}$ from the soil by enhancing availability of $\mathrm{Zn}$ in the rhizosphere (Dong et al., 1995; Cakmak et al., 1996a; Rengel et al., 1998). Genc et al. (2006) reported that several different mechanisms contribute to $\mathrm{Zn}$ efficiency; however, uptake is the major mechanism, and its effect is modified by the physiological efficiency within the barley shoot. Increased Zn uptake might be dependent on root surface area, root colonization by VA mycorrhizae, low $\mathrm{pH}$ in the rhizosphere, release of $\mathrm{Zn}$-chelating phytosiderophores (PS) from the roots and induction of polypeptides involved in $\mathrm{Zn}$ uptake and transport across the plasma membrane(Rengel and Graham, 1995b; Cakmak and Braun, 2001).

Zinc efficiency can be influenced by root morphology, which varies among plant species (Dong et al., 1995). Longer and thinner roots with increased root surface area may influence the availability of $\mathrm{Zn}$ and other nutrients, such as $\mathrm{Cu}, \mathrm{Mn}$ and $\mathrm{Fe}$ (Rengel and Graham, 1995b). Furthermore, soil biological activities, such as root colonization by mycorrhizal fungi, cause increases in the uptake of diffusion-limited nutrients, including $\mathrm{Zn}, \mathrm{P}$ and $\mathrm{Cu}$. Arbuscular mycorrhizae (AM) enable plants to increase $\mathrm{Zn}$ uptake by expanding the volume of soil explored by the root system (Kothari et al., 1991). The fungal hyphae extend from the roots into the soil and explore greater distances compared with root hairs. In maize, AM increase plant $\mathrm{Zn}$ uptake and shoot $\mathrm{Zn}$ content in soils with low concentrations of plantavailable Zn (Faber et al., 1990).

Roots alter the rhizosphere chemistry by changing the rhizosphere $\mathrm{pH}$ (Wang et al., 2006) and/or releasing PS that can chelate soil $\mathrm{Zn}$ and increase its availability 
(Cakmak et al., 1994). The root-mediated decrease in $\mathrm{pH}$ increases $\mathrm{Zn}$ availability by solubilizing $\mathrm{Zn}$ present in inorganic and organic soil complexes (Hacisalihoglu and Kochian, 2003).

A number of studies have focused on the role of root exudates in Zn efficiency. PS are non-proteinogenic amino acids released from roots of graminaceous species under Fe (Marschner, 1995) and Zn (Zhang et al., 1991; Kochian, 1993) deficiency. PS released from roots are highly effective in mobilizing and complexing $\mathrm{Zn}$ in calcareous soils. These compounds are involved in mobilizing $\mathrm{Zn}$ from the root apoplast of wheat plants (Zhang et al., 1991) and may be involved in the translocation and solubility of $\mathrm{Zn}$ within plants (Welch, 1995). Under Zn deficiency, release of PS in $\mathrm{Zn}$-inefficient durum wheat is approximately 6-8 times lower than that in Zn-efficient bread wheat (Cakmak et al., 1996b; Cakmak et al., 1998). In rice grown in nutrient solution, the efficiency of $\mathrm{Zn}$ uptake is correlated with the exudation rates of low molecular weight organic anions (Hoffland et al., 2006).

The results regarding the role of root PS release in Zn efficiency are both contradictory and somewhat controversial. Erenoglu et al. (1996) found that PS release did not correlate with differences in the $\mathrm{Zn}$ efficiency of efficient or inefficient wheat genotypes subjected to $\mathrm{Zn}$ deficiency. In solution culture, zinc deficiency did not significantly induce PS release from barley and wheat cultivars that had been previously reported to exude more PS under Zn deficiency than Zn-inefficient genotypes (Pedler et al., 2000). Although root exudation of PS does not appear to play a major role in $\mathrm{Zn}$ efficiency, it cannot be ruled out as a factor; thus, further studies are warranted (Rengel, 2001).

Compared with Zn-inefficient genotypes, Zn-efficient genotypes can deliver more $\mathrm{Zn}$ from roots to shoots under low $\mathrm{Zn}$ conditions but not under $\mathrm{Zn}$-sufficient conditions (Rengel and Graham, 1995b; Cakmak et al., 1996a). The high Zn efficiency of rye is mainly related to its capacity to take up and translocate $\mathrm{Zn}$ to shoots at much higher rates than other cereals
(Cakmak et al., 1997a). Khan et al. (1998) concluded that efficient $\mathrm{Zn}$ uptake coupled with enhanced root-toshoot transport could be important for Zn efficiency in chickpea genotypes.

Some reports have suggested that $\mathrm{Zn}$ transport from the soil to the root and subsequently to the shoot is not the important factor in differential $\mathrm{Zn}$ efficiency. There are no significant differences in shoot $\mathrm{Zn}$ concentration between inefficient and efficient genotypes grown in soils with low plant-available $\mathrm{Zn}$, even when large differences in visual $\mathrm{Zn}$ deficiency symptoms are observed in contrasting genotypes (Cakmak et al., 1999; Hacisalihoglu et al., 2003). These studies appear to indicate that $\mathrm{Zn}$ efficiency is a shoot-mediated trait. A shoot-mediated mechanism for Zn efficiency could likely involve (1) changes in subcellular $\mathrm{Zn}$ compartmentation and homeostasis such that efficient genotypes accumulate higher levels of $\mathrm{Zn}$ in the cytoplasm of leaf cells and (2) more efficient biochemical use of cellular $\mathrm{Zn}$, such that $\mathrm{Zn}$-requiring macromolecules can efficiently incorporate $\mathrm{Zn}$ as a cofactor under low-Zn conditions (Hacisalihoglu and Kochian, 2003).

The results of leaf tissue compartmentation studies of wheat cultivars grown under low-Zn conditions showed that both the efficient and inefficient cultivars had similar Zn contents in the cytoplasm (9-11\%) and vacuole (83-85\%) (Hacisalihoglu et al., 2003). These results suggest that subcellular $\mathrm{Zn}$ compartmentation may not be involved in Zn efficiency; however, more studies are obviously needed in this area.

Metal-responsive elements (MREs) may play a role in $\mathrm{Zn}$ homeostasis by controlling gene expression in relation to changes in plant metal status. The MREbinding transcription factor-1 (MTF1) mediates the regulation of genes involved in $\mathrm{Zn}$ homeostasis, including responses to both $\mathrm{Zn}$ deficiency and toxicity. MTF1 appears to be involved in the regulation of the free $\mathrm{Zn}$ concentration in the cell by allowing $\mathrm{Zn}$ to bind to MREs and initiate metallothionein gene transcription (Andrews, 2001). 
There is a positive correlation between biochemical utilization involving Zn-requiring enzymes and $\mathrm{Zn}$ efficiency in wheat and bean (Hacisalihoglu et al., 2003). Zn-efficient genotypes might contain a higher amount of $\mathrm{Zn}$ that readily participates in metabolic reactions and binds to $\mathrm{Zn}$-requiring enzymes. $\mathrm{Zn}$ efficient wheat genotypes exhibit increased activity of Zn-requiring enzymes (carbonic anhydrase and $\mathrm{Cu} / \mathrm{Zn}$ superoxide dismutase) than $\mathrm{Zn}$-inefficient genotypes under $\mathrm{Zn}$-deficient conditions and at similar Zn concentrations in leaves (Rengel, 1995; Cakmak et al., 1997c). It is possible that genotypes with the Zn-efficiency trait are better able to utilize $\mathrm{Zn}$ through the action of the Zn-containing enzymes carbonic anhydrase and $\mathrm{Cu} / \mathrm{Zn}$ superoxide dismutase (Hacisalihoglu and Kochian, 2003).

Internal utilization of $\mathrm{Zn}$ is also considered to be an important potential $\mathrm{Zn}$ efficiency mechanism when Zn-efficient and -inefficient plants have similar leaf $\mathrm{Zn}$ concentrations and only $\mathrm{Zn}$-inefficient plants show severe Zn-deficiency symptoms (Rengel and Graham, 1995b). Genc et al. (2002a) indicated that the greater efficiency of barley genotypes may be attributed to more efficient $\mathrm{Zn}$ utilization at the cellular level.

\section{Breeding for $\mathrm{Zn}$ efficiency}

The primary objective of plant breeding has been to enhance farm productivity, usually by developing crops with higher yields. In contrast, improving micronutrient efficiencies and increasing nutrient content in plants has rarely been a breeding objective. In fact, crop nutritional problems have mostly been ignored in breeding.

Some nutritional problems cannot be easily resolved by altering soil fertility or chemistry, and the application of modern breeding techniques to breed crops that are adapted to soils with a poor nutritional status is required. In the case of micronutrient deficiencies induced by high $\mathrm{pH}$ (i.e., $\mathrm{Zn}, \mathrm{Fe}$ and $\mathrm{Mn}$ deficiencies), agronomic solutions (i.e., fertilizers) are not always successful, and a genetic solution is necessary (Cakmak and Braun, 2001). Furthermore, the correction of $\mathrm{Zn}$ deficiency induced by subsoil constraints, topsoil drying and diseases is not effective via fertilization (Graham and Rengel, 1993). Hence, breeding and use of Zn-efficient plant genotypes that can more effectively function under $\mathrm{Zn}$ deficiency is an effective and sustainable solution to address $\mathrm{Zn}$ deficiency limitations in crop production.

Progress has been made with respect to the first stage of breeding, which consists of screening for genetic variability in the trace mineral concentration in plant tissues. Crops show significant genotypic variation with respect to the concentration of minerals such as $\mathrm{Zn}$. For example, in field-grown barley genotypes, the grain $\mathrm{Zn}$ concentrations ranged from 22 to $61 \mathrm{mg} / \mathrm{kg}$ (Sadeghzadeh, 2008). Screening of wheat genotypes revealed grain $\mathrm{Zn}$ concentrations ranging from 14 to $42 \mathrm{mg} / \mathrm{kg}$, and similar ranges of $\mathrm{Zn}$ concentrations were found in rice (Bouis, 1995).

Due to the large genotypic variation in Zn efficiency among crops (Cakmak et al., 1998), there is a need for targeted selection and/or breeding of plants with greater efficiency, both in terms of higher grain yield and grain $\mathrm{Zn}$ content. In the past, lack of a suitable procedure for screening a large number of genotypes in a short time hampered breeding for $\mathrm{Zn}$ efficiency. However, screening in the field at nutrient-responsive sites and comparing yields under limiting and non-limiting rates of $\mathrm{Zn}$ application has been used extensively to assess efficiency (Graham et al., 1992). The results of such screening experiments can be variable because the severity of the nutrient deficiency varies between sites and years due to the effects of other growth-limiting factors, such as drought and diseases. Hence, reliable alternative methods are required.

The use of controlled environments for screening is a common practice. Due to funding and time constraints, the screening of large populations for the development of molecular markers requires a pot culture screening system. Soil-based pot assays under controlled conditions allow for the relative efficiency 
of genotypes to be assessed (Cakmak et al., 1997b; Genc and McDonald, 2004); however, the efficiency is generally assessed based on seedling growth rather than grain yield. Additionally, a major challenge will be to demonstrate the relevance of these screening methods under field conditions.

Lombnaes and Singh (2003) selected four approaches to characterize tolerance to $\mathrm{Zn}$ deficiency in barley and wheat: (1) relative shoot weight at low compared with high Zn supply ("Zn efficiency index"), (2) relative shoot-to-root ratio at low compared with high $\mathrm{Zn}$ supply, (3) total shoot uptake of $\mathrm{Zn}$ under deficient conditions and (4) shoot dry weight under deficient conditions. Evaluating the severity of $\mathrm{Zn}$ deficiency symptoms on leaves together with the $Z n$ efficiency ratio (yield under $-\mathrm{Zn}$ / yield under $+\mathrm{Zn}$ ) appears to be a reasonable approach for reliably and quickly screening large numbers of genotypes for $\mathrm{Zn}$ efficiency within a short time (Cakmak and Braun, 2001; Genc et al., 2003).

\section{Role of high $\mathrm{Zn}$ reserves in seeds}

Some crop genotypes have a large capacity to take up trace minerals and accumulate them in the grain, even when grown in soils with low plant-available micronutrients (Graham and Welch, 1996); however, the physiological processes controlling micronutrient accumulation in seeds are not well understood (Welch and Graham, 2002). Micronutrient uptake and accumulation traits in plants are heritable and could therefore be improved by selective breeding. Hence, screening for genetic variability in these traits is commonly the first step in plant breeding. There is significant genotypic variation for seed $\mathrm{Zn}$ accumulation in several staple crops, including rice, wheat, maize and bean (Gregorio et al., 2000; Genc et al., 2002b; Mantovi et al., 2003). For example, the seed $\mathrm{Zn}$ concentration of wheat cultivars ranged from 25 to $64 \mathrm{mg} / \mathrm{kg}$ (Frossard et al., 2000), and the seed Zn content of field-grown barley varied from 0.7 to $2.9 \mu \mathrm{g} /$ seed (Sadeghzadeh, 2008). There is increasing evidence that an elevated grain nutrient concentration may allow good crop establishment when such seeds are sown in soils with low plant-available nutrients. Sowing seeds with high $\mathrm{Zn}$ concentration can be a practical solution for increasing yield under $\mathrm{Zn}$ deficiency (Cakmak and Braun, 2001). In glasshouse experiments, wheat plants grown from high-Zn seed had improved growth and grain yield compared with plants derived from seed with low Zn content (Rengel and Graham, 1995a). In Zn-deficient fields, wheat plants derived from seed with high and intermediate $\mathrm{Zn}$ content had a significantly greater grain yield compared with plants grown from seed with low Zn content (Cakmak and Braun, 2001). In barley, Genc et al. (2000) reported that high seed Zn content significantly reduced the visual $\mathrm{Zn}$ deficiency symptoms and improved vegetative growth, especially when the $\mathrm{Zn}$ supply from the rooting medium was deficient for plant growth.

Breeding for micronutrient-dense seeds can confer resistance to root diseases, resulting in lower dependence on fungicides. Seed nutrient levels that fail to provide enough nutrition to seedlings in deficient soils may greatly increase plant susceptibility to some diseases, especially fungal root diseases of major crops (Streeter et al., 2001). From an agronomic point of view, micronutrient-dense seeds may have enough nutrient reserves to last until a large root system is developed to compensate for the low nutrient supply in micronutrient-poor soils.

Enhancing the nutrient content and nutritional quality of crops for the purpose of improving human nutrition is currently a global challenge because it has been mostly ignored by previous breeding programs. Recently, interest in increasing the micronutrient concentration in crop grains has been increasing (Welch and Graham, 2002; Welch and Graham, 2004; Uauy et al., 2006). Such increases result in improved human health and better crop production. The micronutrient concentration in grains destined for human consumption is a more important parameter than the micronutrient content. The nutrient concentration in seeds is dependent on the parental plant growth conditions, including soil type, nutrient availability, crop species and genotype. 
It is desirable to combine the ability to load $\mathrm{Zn}$ into the grain with a high yield potential. Efficient $\mathrm{Zn}$ uptake from the soil and efficient $\mathrm{Zn}$ loading into the seed are achievable together with high yield through breeding techniques. The grain $\mathrm{Zn}$ concentration of a genotype reflects its ability to take up $\mathrm{Zn}$ from the soil, mobilize $\mathrm{Zn}$ from different parts of the plant and load $\mathrm{Zn}$ in the grain (Genc et al., 2006). However, to obtain reliable information regarding the level of genetic variation in grain nutrient concentration, any possible dilution and concentration effects associated with differences in yield potential must be taken into account. Farmers can be expected to adopt genotypes with $\mathrm{Zn}$-dense seeds to achieve higher profits. The use of seed with high $\mathrm{Zn}$ content could provide a practical approach for alleviating the Zn-deficiency problem, especially when farmers are not aware of Zn deficiency and in areas where $\mathrm{Zn}$ fertilization is not practical.

\section{Genotypic variation in $\mathrm{Zn}$ efficiency}

Plant genotypes vary widely with respect to their tolerance to $\mathrm{Zn}$ deficiency, both in terms of $\mathrm{Zn}$ utilization and uptake. A wide range of wheat, barley, rice, bean, chickpea and maize germplasms has been studied, indicating there is enough genotypic variation to allow breeding for nutritional improvement (Gregorio et al., 2000). Nutritional traits are generally stable across environments, despite some reported genotype by environment ( $\mathrm{G} \times \mathrm{E}$ ) interactions. Thus, it is possible to combine high micronutrient traits with high yield.

Rengel and Wheal (1997) indicated that the differences in $\mathrm{Zn}$ efficiency between wheat cultivars are closely related to differences in $\mathrm{Zn}$ uptake capacity. Similarly, the higher $\mathrm{Zn}$ efficiency of rye versus wheat cultivars is accompanied by an increase in the $\mathrm{Zn}$ concentration of shoots; rye has a higher genetic ability to absorb $\mathrm{Zn}$ from soils with low plant-available $\mathrm{Zn}$ (Cakmak et al., 1997a). In field experiments performed on $\mathrm{Zn}$ deficient calcareous soils, $\mathrm{Zn}$ efficiency was positively correlated with the total amount (uptake) of $\mathrm{Zn}$ in shoots (Graham et al., 1992; Cakmak et al., 1997b).
Although Zn-efficient genotypes have greater $\mathrm{Zn}$ uptake ability, they do not necessarily have a higher $\mathrm{Zn}$ concentration (amount of $\mathrm{Zn}$ per unit of dry weight) in leaves, shoots or grains (Graham et al., 1992). Zninefficient wheat genotypes may even have greater $\mathrm{Zn}$ concentrations in leaves or grains than $\mathrm{Zn}$-efficient genotypes (Cakmak et al., 1997b; Cakmak et al., 1998). Under Zn deficiency, increased Zn uptake by efficient genotypes improves dry matter production and results in corresponding decreases in $\mathrm{Zn}$ concentration similar to those present in $\mathrm{Zn}$-inefficient genotypes (i.e., dilution due to growth) (cf. Marschner, 1995).

\section{Genetics of $\mathrm{Zn}$ efficiency}

Most research related to $\mathrm{Zn}$ efficiency in crops has concentrated on the physiological aspects of $\mathrm{Zn}$ uptake or has compared genotypes with respect to their relative efficiency to grow in soils with low plant-available $\mathrm{Zn}$. Although some physiological mechanisms involved in $\mathrm{Zn}$ efficiency have been documented, limited information is available on the genetic control of these mechanisms and the molecular backgrounds or genes responsible for $\mathrm{Zn}$ efficiency. An understanding of the genetic variability for $\mathrm{Zn}$ efficiency and its simple inheritance pattern could allow progress toward improving $\mathrm{Zn}$ efficiency in crops.

A limited number of studies have yielded some preliminary evidence regarding the genetics of $\mathrm{Zn}$ efficiency in several crop species. Studies of chromosome addition lines in rye have shown that $\mathrm{Cu}$, $\mathrm{Zn}$ and Mn efficiencies were independent characteristics and were located on different chromosomes. The results from a diallel analysis in rice suggested that the genes controlling $\mathrm{Zn}$ efficiency are additive and, to a lesser degree, dominant (Majumder et al., 1990). In maize, four additive genes were reported to affect the $\mathrm{Zn}$ concentration in the ear leaf (El-Bendary et al., 1993). Several loci on chromosomes $1 \mathrm{R}, 2 \mathrm{R}$ and $7 \mathrm{R}$ enhance $\mathrm{Zn}$ efficiency in rye, with genes on the short arms of $1 \mathrm{R}$ and $7 \mathrm{R}$ being the most effective (Cakmak et al., 1997a). The distribution of $\mathrm{F} 3$ populations from across between $\mathrm{Zn}$-efficient and $\mathrm{Zn}$-inefficient 
genotypes showed that only a few genes control $\mathrm{Zn}$ efficiency in soybean based on measurements of foliar $\mathrm{Zn}$ concentrations (Hartwing et al., 1991). The results from a diallel experiment comparing seven wheat cultivars differing in $\mathrm{Zn}$ efficiency with their F1 derivatives showed that genes controlling $\mathrm{Zn}$ efficiency are dominant (Cakmak and Braun, 2001).

As in Thlaspi species, the over expression of $\mathrm{Zn}$ transporters in cereals may affect plant growth, seed mineral content and $\mathrm{Zn}$ transport rates. Lasat et al. (1996) found that enhanced expression of genes encoding $\mathrm{Zn}$ transporters can increase $\mathrm{Zn}$ uptake in Thlaspi caerulescens and T. arvense. Further study in this system revealed that a Zn transporter gene, ZNT1, was highly expressed in $T$. caerulescens, allowing enhanced Zn uptake (Lasat et al., 2000; Pence et al., 2000; Assuncao et al., 2001). The ZNT1 gene is a member of the ZIP family of metal transporters (Guerinot, 2000), which are known to transport a variety of divalent cations. Transgenic Arabidopsis over expressing the plasma membrane ion transporter gene ZAT exhibited enhanced $\mathrm{Zn}$ content in the roots when the plants were grown under high external $\mathrm{Zn}$ (Van der Zaal et al., 1999). In barley, over expression of an Arabidopsis $\mathrm{Zn}$ transporter increased shortterm $\mathrm{Zn}$ uptake and seed cation content (Ramesh et al., 2004).

Uauy (2006) reported that reduction in the RNA levels of the T. aestivum No Apical Meristem (TaNAM) genes is associated with a decrease in wheat grain $\mathrm{Zn}$ and $\mathrm{Fe}$ concentrations and an increase in residual $\mathrm{N}$, $\mathrm{Zn}$ and $\mathrm{Fe}$ in the flag leaf. These results suggest that the reduced grain $\mathrm{Zn}$ and $\mathrm{Fe}$ concentrations were the result of reduced translocation from leaves rather than the result of a dilution effect caused by larger grains.

Using visual $\mathrm{Zn}$ deficiency symptoms, it was reported that a single dominant gene controls tolerance to $\mathrm{Zn}$ deficiency in common bean (Singh and Westermann, 2002). Genc et al. (2003) determined the inheritance of $\mathrm{Zn}$ efficiency in barley using a visual score of deficiency symptoms and reported that tolerance to
Zn deficiency at the seedling stage is controlled by a single gene with no dominance.

\section{Identifying molecular markers for $\mathrm{Zn}$ efficiency}

Selection using molecular markers could be an efficient complementary breeding tool, especially when selection is performed under unfavorable conditions (Cakmak and Braun, 2001). Molecular markers for Mn efficiency have been identified in barley (Pallotta et al., 2000), and putative markers have been identified in durum wheat (Khabaz-Saberi et al., 2002). Screening for higher seed $\mathrm{Zn}$ accumulation in double haploid populations arising from a cross between $\mathrm{Zn}$ efficient and $\mathrm{Zn}$-inefficient genotypes could lead to the development of molecular markers for $\mathrm{Zn}$ efficiency.

Molecular markers can be broadly classified into the following three groups: hybridization-based markers, such as restriction fragment length polymorphism (RFLPs); DNA chip- and sequencing-based markers, such as single nucleotide polymorphism (SNPs); and PCR-based markers, such as random amplified polymorphic DNA (RAPD), simple sequence repeats (SSRs), sequence tagged sites (STS), amplified fragment length polymorphisms (AFLPs), microsatellite-anchored fragment length polymorphisms (MFLPs) and others.

With the ever-increasing number of linkage maps being produced by various research groups, it is anticipated that the mapping of nutritional characteristics will become more common. Before developing a genetic linkage map and identifying molecular markers, large mapping populations that segregate for the particular trait must be produced. Wide crosses usually provide segregating populations with a relatively large array of polymorphisms.

The most commonly used plant materials for genetically dissecting and mapping traits are segregating populations descended from two varieties showing divergence for the target trait(s). F2 populations are suitable for mapping; however, 
when traits are controlled by multiple genes, more advanced generations are needed to minimize environmental effects on traits. Development of a complete genetic linkage map requires genetically stable selfed populations that have advanced through several recombination cycles via self-pollination. Doubled haploid and recombinant inbred lines (RILs) provide permanent mapping resources. In addition, doubled haploid lines (DH) and RILs are very useful for mapping because phenotypic analysis is carried out using several plants from each family rather than a single F2 plant. Thus, the analysis is more accurate, and the total population size required is smaller than that required with an F2 population. DH lines and RILs are also better suited for the analysis of quantitative traits.

Polymorphic molecular markers are used for genotyping a segregating population during the development of a linkage map. By statistically evaluating segregating marker alleles and linkages among different marker alleles from previous studies, markers can be placed in linkage groups. When marker locations in the genome are known (e.g., RFLPs or SSRs), linkage groups can be assigned to chromosomes. When the genome of a crop species has adequate marker coverage, the number of linkage groups observed should match the number of haploid chromosomes in the genome (i.e., the barley linkage map should have 7 linkage groups). Although constructing a linkage map is necessary for identifying genes controlling quantitative traits, when the target trait is regulated by major genes, a full linkage map is not always required to identify genes and associate them with markers (Ribaut et al., 2001).

The next step after constructing a linkage map is to identify the chromosomal location of the genetic locus by identifying a DNA marker that co-segregates with the trait of interest, such as $\mathrm{Zn}$ accumulation. Theoretically, tightly linked DNA markers can speed up the breeding process because breeders may then select for the DNA markers rather than attempting more expensive, time-consuming bioassays or relying on field data. Effective mapping studies depend on two types of data: field or glasshouse data on the segregation of the trait(s) and laboratory data on marker segregation. The quality of the phenotypic data is crucial for the success of gene/QTL analysis because laboratory data on marker segregation within a population must be correlated with field or glasshouse data to identify QTLs. Therefore, phenotypic evaluation must be carefully planned and performed with adequate replications to minimize error (Ribaut et al., 2001).

QTLs are genetic factors that are responsible for a fraction of the observed phenotypic variation in a quantitative trait. QTL analysis for cereal grain quality traits has been pursued by several research groups (Septiningsih et al., 2003; Li et al., 2004). To identify the genetic loci involved in establishing seed Zn content in Arabidopsis, Vreugdenhil et al. (2004) identified four QTLs on chromosomes 1, 2, 3 and 5 that are involved in seed $\mathrm{Zn}$ content and explain up to $42 \%$ of the variation. In an F2 cross of Arabidopsis halleri with A. petraea, three QTLs were identified on chromosomes 4, 6 and 7 that are involved in determining the seed $\mathrm{Zn}$ content (Filatov et al., 2007). In common bean, one QTL on linkage group IV was associated with seed $\mathrm{Zn}$ content, explaining 15\% of the phenotypic variance for this trait (GuzmanMaldonado et al., 2003). Using RILs from the cross W7984 x Opata 85, Balint et al. (2007) identified QTLs controlling shoot $\mathrm{Zn}$ and Mn contents on wheat chromosomes $3 \mathrm{AL}$ and $3 \mathrm{BL}$, respectively.

In a DH barley population derived from a cross between Clipper and Sahara, Lonergan et al. (2001) identified a region on the long arm of chromosome $4 \mathrm{H}$ as being associated with both shoot $\mathrm{Zn}$ concentration and content. In a related study, one QTL on the short arm of chromosome $2 \mathrm{H}$ was also found to be involved with increased seed $\mathrm{Zn}$ content in barley (Lonergan, 2001).

In another study on 150 doubled haploids from the Clipper $\times$ Sahara cross grown in the field and glasshouse, Sadeghzadeh et al. (2008) identified two regions located on chromosomes $2 \mathrm{HS}$ and $2 \mathrm{HL}$ that were associated with seed $\mathrm{Zn}$ concentration and 
content of field-grown plants. The first region was flanked by the RFLP markers Xbcd175 and Xpsr108; the second region was flanked by the morphological marker for six/two rowed ear-types, vrs1, and the RFLP marker XksuF15. These two regions accounted for $45 \%$ of the total variation in seed $\mathrm{Zn}$ concentration and 59\% of the total variation in seed $\mathrm{Zn}$ content. In a glasshouse experiment, these two regions located on $2 \mathrm{HS}$ and 2HL were also associated with seed $\mathrm{Zn}$ concentration and content, and they explained $37 \%$ and $55 \%$ of the total variation in seed $\mathrm{Zn}$ concentration and content, respectively. Furthermore, in a glasshouse experiment, two additional QTLs were detected on chromosomes $3 \mathrm{HL}$ and $4 \mathrm{HS}$, explaining $13 \%$ of the phenotypic variance in seed Zn concentration (Sadeghzadeh et al., 2013).

Moreover, Sadeghzadeh et al. (2008) identified one dominant DNA polymorphism using the MFLP technique. Then, the candidate MFLP marker was converted into a simple sequence-specific and PCRbased marker. This converted sequence-specific marker, designated SZnR1 (Seed Zn Regulator-1), is located on the short arm of chromosome $2 \mathrm{H}$ and might be useful in marker-assisted selection (MAS) for the improvement of barley productivity and nutritional quality in $\mathrm{Zn}$-deficient environments.

Verification of QTLs is necessary prior to their use in MAS for cultivar improvement. Putative QTLs could not be confirmed in an independent set of genotypes obtained from the same cross used for mapping (Romagosa et al., 1999), which may occur when QTLs are not accurately located in the genome and the flanking molecular markers used do not adequately tag the desirable alleles. A vanishing QTL may also be due to other factors, such as inaccurate phenotyping, accepting a QTL with marginal logarithm of odds (LOD) score and a small sample size. Thus, confirmation of the QTL effects in an independent sample of genotypes within the same cross is warranted. Using a different population from the same cross allows different environmental effects and QTL $\times$ environment interactions for a putative QTL to be tested (Romagosa et al., 1999).
A significant development that is likely to occur in the next few years will be the use of markers to identify desirable $\mathrm{Zn}$ efficiency gene(s). Markers will allow selection for $\mathrm{Zn}$ efficiency independently of the environmental variability or the growth stage. If markers are close enough to the gene of interest, they can be directly used for MAS. One of the major drawbacks occurs when the linked marker used for selection is distant from the gene of interest, leading to potential crossovers between the marker and the gene. This produces a high percentage of false positives or negatives during the screening process (Mohan et al., 1997). Hence, marker density and the accuracy of the current unsaturated genetic maps should be increased, and additional markers are needed to facilitate MAS for complex traits such as $\mathrm{Zn}$ efficiency and identification of relevant gene(s). PCR-based markers, such as AFLPs, SSRs and MFLPs, can be used to increase the number of loci on the genetic map and thus increase map saturation (Karakousis et al., 2003). With a more saturated map, the genomic position of loci controlling high $\mathrm{Zn}$ accumulation can be determined more accurately than with current genetic maps.

Following QTL identification, candidate loci or genes can be determined through fine mapping and mapbased cloning, and this information could be used for MAS breeding. Importantly, knowledge regarding the genes and/or chromosomal loci controlling seed or shoot $\mathrm{Zn}$ in one plant species can be used in different target crops by exploiting gene homology and/or genome collinearity (Ghandilyan et al., 2006).

\section{Conclusions}

Low plant availability of soil $\mathrm{Zn}$ is a critical problem for cereal production, causing severe reduction in yield and nutritional quality of the grains. Combining improved tolerance to $\mathrm{Zn}$ deficiency in soils and increased $\mathrm{Zn}$ concentration and content in seeds is a high priority research topic, especially in $\mathrm{Zn}$-deficient areas. High $\mathrm{Zn}$ efficiency in crops appears to be 
related to various morphological and physiological traits, such as root surface area, Zn-mobilizing root exudates and better utilization of $\mathrm{Zn}$ at the cellular level. However, finding a solution to Zn deficiency requires a comprehensive exploration of potential genetic resources and an in-depth understanding of their role in micronutrient accumulation mechanisms.

Field and growth room screening revealed significant genetic variation for $\mathrm{Zn}$ efficiency in cereals, suggesting that selection for improved $\mathrm{Zn}$ efficiency is possible. Evaluating the severity of $\mathrm{Zn}$ deficiency symptoms on leaves as well as monitoring shoot and seed $\mathrm{Zn}$ concentration and content appear to be useful approaches for screening large populations for $\mathrm{Zn}$ efficiency. However, the variability inherent in field and growth room screening has produced some inconsistent results. In view of the difficulty in developing fast and reliable screening methods for $\mathrm{Zn}$ efficiency (such as seedling selection in pots) that accurately reflect field screening, molecular markers for $\mathrm{Zn}$ efficiency are considered important for success in cereal breeding programs. A lack of suitable markers for Zn efficiency has long hampered the application of this idea in practice.

Markers are now applied routinely to replace timeconsuming or expensive tests. As technology continues to evolve, the availability of markers at low costs will become a reality for many crops. This opens up a range of new options through which information obtained from linkage between markers and genes or QTLs can be utilized. It is essential that plant breeders make use of all tools at hand to develop improved varieties. The recent identification of DNA markers that are diagnostic of Zn efficiency will accelerate the development of cultivars that can remain productive on soils with low plant-available $\mathrm{Zn}$. Additionally, these markers may be used to begin identifying the specific genes responsible for differences in the response of crops to $\mathrm{Zn}$ deficiency.

\section{References}

Alloway, B.J., 2001. Zinc - the vital micronutrient for healthy, high-value crops. International Zinc Association, Brussels.

Alloway, B.J., 2004. Zinc in Soils and Crop Nutrition. International Zinc Association Communications. IZA publications, Brussels, Belgium.

Andrews, G.K., 2001. Cellular zinc sensors: MTF1 regulation of gene expression. Biometals. 14, 223-237.

Assuncao, A.G.L., Da Costa Martins, P., De Folter, S., Vooijs, R., Schat, H., Aarts, M.G.M., 2001. Elevated expression of metal transporter genes in three accessions of the metal hyperaccumulator Thlaspi caerulescens. Plant, Cell Environ. 24, 217-226.

Balint, A.F., Roder, M.S., Hell, R., Galiba, G., Borner, A., 2007. Mapping of QTLs affecting copper tolerance and the $\mathrm{Cu}, \mathrm{Fe}, \mathrm{Mn}$ and $\mathrm{Zn}$ contents in the shoots of wheat seedlings. Biologia plantarum. 51, 129-134.

Biesalski, H.K., 2013. Hidden Hunger. Springer.

Bouis, H., 1995. Enrichment of food staples through plant breeding: a new strategy for fighting micronutrient malnutrition. Administrative Committee on Coordination-Subcommittee on Nutrition of the United Nations. ACC/SCN c/o WHO, Geneva, Switzerland. SCN News 12, 1519.

Cakmak, I., 2004. Identification and correction of widespread zinc deficiency in Turkey - a success story (a NATO-Science for Stability Project). Proceedings of the International Fertiliser Society. 552, 1-26.

Cakmak, I., Braun, H.J., 2001. Genotypic variation for zinc efficiency. In: Reynolds, M.P., Ortiz- 
Monasterio, J.I., McNab, A. (Eds.), Application of Physiology in Wheat Breeding. D.F. CIMMYT, pp. 183-199, Mexico, pp. 183-199.

Cakmak, I., Derici, R., Torun, B., Tolay, I., Braun, H.J., Schlegel, R., 1997a. Role of rye chromosome in improvement of zinc efficiency in wheat and triticale. Plant and soil. 196, 249-253.

Cakmak, I., Ekiz, H., Yilmaz, A., Torun, B., Koleli, N., Gultekin, I., Alkan, A., Eker, S., 1997b. Differential response of rye, triticale, bread and durum wheats to zinc deficiency in calcareous soils. Plant and Soil. 188, 1-10.

Cakmak, I., Gulut, K.Y., Marschner, H., Graham, R.D., 1994. Effect of zinc and iron deficiency on phytosiderophore release in wheat genotypes differing in zinc efficiency. Journal of Plant Nutrition. 17, 1-17.

Cakmak, I., Kalayci, M., Ekiz, H., Braun, H.J., Kilinc, Y., Yilmaz, A., 1999. Zn deficiency as a practical problem in plant and human nutrition in Turkey: a NATO-Science for stability project. Field Crop Research. 60, 175-188.

Cakmak, I., Marschner, H., Bangerth, F., 1989. Effect of zinc nutritional status on growth, protein metabolism and levels of indole-3-acetic acid and other phytohormones in bean (Phaseolus vulgaris L.). Journal of Experimental Botany. 40, 405-412.

Cakmak, I., Oztürk, L., Eker, S., Torun, B., Kalfa, H.I., Y1lmaz, A., 1997c. Concentration of zinc and activity of copper/zinc-superoxide dismutase in leaves of rye and wheat cultivars differing in sensitivity to zinc eficiency. Journal of Plant Physiology. 151, 91-95.

Cakmak, I., Sari, N., Marschner, H., Kalayci, M., Yilmaz, A., Eker, S., Gulut, K.Y., 1996a. Dry matter production and distribution of zinc in bread and durum wheat genotypes differing in $\mathrm{Zn}$ efficiency. Plant and soil. 180, 173-181.
Cakmak, I., Sary, N., Marschner, H., Ekiz, H., Kalaycy, M., Yilmaz, A., Braun, H.J., 1996b. Phytosiderophore release in bread and durum wheat genotypes differing in zinc efficiency. Plant and Soil. 180, 183-189.

Cakmak, I., Torun, B., Erenoglu, B., Ozturk, L., Marschner, H., Kalayci, M., Ekiz, H., Yilmaz, A., 1998. Morphological and physiological differences in the response of cereals to zinc deficiency. Euphytica. 100, 349-357.

Chatterjee, C., Khurana, N., 2007. Zinc stress-induced changes in biochemical parameters and oil content of mustard. Communications in Soil Science and Plant Analysis. 38, 751-761.

Dong, B., Rengel, Z., Graham, R.D., 1995. Root morphology of wheat genotypes differing in zinc efficiency. Journal of Plant Nutrition. 18, 27612773 .

El-Bendary, A.A., El-Fouly, M.M., Raksa, F.A., Omar, A.A., Abou-Youssef, A.Y., 1993. Mode of inheritance of zinc accumulation in maize. Journal of plant nutrition. 16, 2043-2053.

Erenoglu, B., Cakmak, I., Marschner, H., Romheld, V., Eker, S., Daghan, H., Kalayci, M., Ekiz, H., 1996. Phytosiderophore release does not relate well with zinc efficiency in different bread wheat genotypes. Journal of plant nutrition. 19, 1569-1580.

Faber, B.A., Zasoski, R.J., Burau, R.G., Uriu, K., 1990. Zinc uptake by corn as affected by vesicular-arbuscular mycorrhizae. Plant and Soil. 129, 121-130.

Figueiredo, D.D., Barros, P.M., Cordeiro, A.M., Serra, T.S., Lourenço, T., Chander, S., Oliveira, M.M., Saibo, N.J., 2012. Seven zinc-finger transcription factors are novel regulators of the stress responsive gene OsDREB1B. Journal of Experimental Botany. 63, 3643-3656. 
Filatov, V., Dowdle, J., Smirnoff, N., FordLloyd, B., Newbury, H.J., Macnair, M.R., 2007. A quantitative trait loci analysis of zinc hyperaccumulation in Arabidopsis halleri. New Phytologist. 174, 580-590.

Frossard, E., Bucher, M., Mächler, F., Mozafar, A., Hurrell, R., 2000. Potential for increasing the content and bioavailability of $\mathrm{Fe}, \mathrm{Zn}$ and $\mathrm{Ca}$ in plants for human nutrition. Journal of the Science of Food and Agriculture. 80, 861-879.

Genc, Y., McDonald, G.K., 2004. The potential of synthetic hexaploid wheats to improve zinc efficiency in modern bread wheat. Plant and soil. 262, 23-32.

Genc, Y., McDonald, G.K., Graham, R.D., 2000. Effect of seed zinc content on early growth of barley (Hordeum vulgare L.) under low and adequate soil zinc supply. Australian Journal of Agricultural Research. 51, 37-45.

Genc, Y., McDonald, G.K., Graham, R.D., 2002a. Critical deficiency concentration of zinc in barley genotypes differing in zinc efficiency and its relation to growth responses. Journal of Plant Nutrition. 25, 545-560.

Genc, Y., McDonald, G.K., Graham, R.D., 2002b. A soil-based method to screen for zinc efficiency in seedlings and its ability to predict yield responses to zinc efficiency in mature plants. Australian Journal of Agricultural Research. 53, 409-421.

Genc, Y., McDonald, G.K., Graham, R.D., 2006. Contribution of different mechanisms to zinc efficiency in bread wheat during early vegetative stage. Plant and soil. 281, 353-367.

Genc, Y., Shepherd, K.W., McDonald, G.K., Graham, R.D., 2003. Inheritance of tolerance to zinc deficiency in barley. Plant Breeding. 122, 283284.
Ghandilyan, A., Vreugdenhil, D., Aarts, M.G.M., 2006. Progress in the genetic understanding of plant iron and zinc nutrition. Physiologia Plantarum. 126, 407-417.

Graham, R.D., Ascher, J.S., Hynes, S.C., 1992. Selecting zinc-efficient cereal genotypes for soils of low zinc status. Plant and Soil. 146, 241-250.

Graham, R.D., Rengel, Z., 1993. Genotypic variation in Zn uptake and utilization by plants. In: Robson, A.D. (Ed.), Zinc in Soils and Plants. Kluwer Academic Publishers, pp. 107-114, Dordrecht, The Netherlands, pp. 107-114.

Graham, R.D., Welch, R.M., 1996. Breeding for staple-food crops with high micronutrient density. Working Papers on Agricultural Strategies for Micronutrients, No. 3. International Food Policy Research Institute, Washington, D.C.

Gregorio, G.B., Senadhira, D., Htut, T., Graham, R.D., 2000. Breeding for trace mineral density in rice. Food and Nutrition Bulletin 21, 382-386.

Guerinot, M.L., 2000. The ZIP family of metal transporters. Biochimica et Biophysica Acta. 1465, 190-198.

Guzman-Maldonado, S.H., Martinez, O., AcostaGallegos, J.A., Guevara-Lara, F., Paredes-Lopez, O., 2003. Putative quantitative trait loci for physical and chemical components of common bean. Crop Science. 43, 1029-1035.

Hacisalihoglu, G., Hart, J.J., Kochian, L.V., 2001. High- and low-affinity zinc transport systems and their possible role in zinc efficiency in bread wheat. Plant physiology. 125, 456-463.

Hacisalihoglu, G., Hart, J.J., Wang, Y., Cakmak, I., Kochian, L.V., 2003. Zinc efficiency is correlated with enhanced expression and activity of $\mathrm{Cu} / \mathrm{Zn}$ superoxide dismutase and carbonic anhydrase in wheat. Plant Physiology. 131, 595-602. 
Hacisalihoglu, G., Kochian, L.V., 2003. How do some plants tolerate low levels of soil zinc? Mechanisms of zinc efficiency in crop plants. New Phytologist. 159, 341-350.

Hartwing, E.E., Jones, W.F., Kilen, T.C., 1991. Identification and inheritance of inefficient zinc absorption in soybean. Crop Science. 31, 61-63.

Hoffland, E., Wei, C., Wissuwa, M., 2006. Organic anion exudation by lowland rice (Oryza sativa L.) at zinc and phosphorus deficiency. Plant and Soil. $283,155-162$.

Karakousis, A., Gustafson, J.P., Chalmers, K.J., Barr, A.R., Langridge, P., 2003. A consensus map of barley integrating SSR, RFLP, and AFLP markers. Australian Journal of Agricultural Research. 54, 1173-1185.

Khabaz-Saberi, H., Graham, R.D., Pallotta, M.A., Rathjen, A.J., Williams, K.J., 2002. Genetic markers for manganese efficiency in durum wheat. Plant breeding. 121, 224-227.

Khan, H.R., McDonald, G.K., Rengel, Z., 1998. Chickpea genotypes differ in their sensitivity to $\mathrm{Zn}$ deficiency. Plant and Soil. 198, 11-18.

Kochian, L.V., 1993. Zinc absorption from hydroponic solutions by plant roots. In: Robson, A.D. (Ed.), Zinc in Soils and Plants. Kluwer Academic Publishers, pp. 45-57, Dordrecht, The Netherlands, pp. 45-57.

Kothari, S.K., Marschner, H., Romheld, V., 1991. Contribution of VA mycorrhizal hyphae in acquisition of phosphorus and zinc by maize grown calacareous soil. Plant and Soil. 131, 177-185.

Lasat, M.M., Baker, A.J.M., Kochian, L.V., 1996. Physiological characterization of root $\mathrm{Zn}^{2+}$ absorption and translocation to shoots in $\mathrm{Zn}$ hyperaccumulator and nonaccumulator species of Thlaspi. Plant physiology. 112, 1715-1722.
Lasat, M.M., Kochian, L.V., 2000. Physiology of Zn hyperaccumulation in Thlaspi caerulescens. In: Terry, N., Banuelos, G. (Eds.), Phytoremediation of Contaminated Soil and Water. CRC Press LLC, pp. 159-169, Boca Raton, FL, USA, pp. 159-169.

Lasat, M.M., Pence, N.S., Garvin, D.F., Ebbs, S.D., Kochian, L.V., 2000. Molecular physiology of zinc transport in the $\mathrm{Zn}$ hyperaccumulator Thlaspi caerulescens. Journal of Experimental Botany. 51, 71-79.

Li, H.Y., Zhu, Y.G., Smith, S.E., Smith, F.A., 2003. Phosphorus-zinc interactions in two barley cultivars differing in phosphorus and zinc efficiencies. Journal of Plant Nutrition. 26, 10851099.

Li, J., Xiao, J., Grandillo, S., Jiang, L., Wan, Y., Deng, Q., Yuan, L., McCouch, S.R., 2004. QTL detection for rice grain quality traits using an interspecific backcross population derived from cultivated Asian (O. sativa L.) and African ( $O$. glaberrima S.) rice. Genome. 47, 697-704.

Lombnaes, P., Singh, B.R., 2003. Varietal tolerance to zinc deficiency in wheat and barley grown in chelator-buffured nutrient solution and its effect on uptake of $\mathrm{Cu}, \mathrm{Fe}$, and $\mathrm{Mn}$. Journal of Plant Nutrition and Soil Science. 166, 76-83.

Loneragan, J.F., Webb, M.J., 1993. Interactions between zinc and other nutrients affecting the growth of plants. In: Robson, A.D. (Ed.), Zinc in Soils and Plants. Kluwer Academic Publishers, pp. 119-134, Dordrecht, The Netherlands, pp. 119-134.

Lonergan, P.F., 2001. Genetic Characterisation and QTL Mapping of Zinc Nutrition in Barley (Hordeum vulgare). $\mathrm{PhD}$ thesis. Faculty of Agriculture and Natural Resource Sciences. The University of Adelaide, Australia. 
Lonergan, P.F., Graham, R.D., Barker, S.J., Paull, J.G., 2001. Mapping of chromosome regions associated with increased vegetative zinc accumulation using a barley doubled haploid population. Developments in Plant and Soil Sciences. 92, 84-85.

Majumder, N.D., Rakshit, S.C., Borthakur, D.N., 1990. Genetic effects on uptake of selected nutrients in some rice (Oryza sativa L.) varieties in phosphorus deficient soil. Plant and Soil. 123, 117-120.

Mantovi, P., Bonazzi, G., Maestri, E., Marmiroli, N., 2003. Accumulation of copper and zinc from liquid manure in agricultural soils and crop plants. Plant and Soil. 250, 249-257.

Marschner, H., 1995. Mineral Nutrition of Higher Plants, 2nd ed. Academic Press, London.

McDonald, G.K., Graham, R.D., Lloyd, J., Lewis, J., Lonergan, P., Khabaz-Saberi, H., 2001. Breeding for improved zinc and manganese efficiency in wheat and barley. Proceeding of the 10th Australian Agronomy Conference. Department of Plant Science, Waite Institute, Glen Osmond, SA, Hobart.

Mohan, M., Nair, S., Bhagwat, A., Krishna, T.G., Yano, M., Bhatia, C.R., Sasaki, T., 1997. Genome mapping, molecular markers and marker-assisted selection in crop. Molecular Breeding. 3, 87-103.

Moraghan, J.T., Mascagni Jr, H.J., 1991 . Environmental and soil factors affecting micronutrient deficiencies and toxicities. In: Mordvedt, J.J., Cox, F.R., Shumann, L.M., Welch, R.M. (Eds.), Micronutrients in Agriculture. Soil Science Society of America, pp. 371-425, Madison, WI, pp. 371-425.

Pallotta, M.A., Graham, R.D., Langridge, P., Sparrow, D.H.B., Barker, S.J., 2000. RFLP mapping of manganese efficiency in barley. Theoretical and Applied Genetics. 101, 1100-1108.
Parker, M.B., Walker, M.E., 1986. Soil pH and manganese effects on manganese nutrition of peanut. Agronomy Journal. 78, 614-620.

Pedler, J.F., Parker, D.R., Crowley, D.E., 2000. Zinc deficiency-induced phytosiderophore release by the Triticaceae is not consistently expressed in solution culture. Planta. 211, 120-126.

Pence, N.S., Larsen, P.B., Ebbs, S.D., Letham, D.L.D., Lasat, M.M., Garvin, D.F., Eide, D., Kochian, L.V., 2000. The molecular physiology of heavy metal transport in the $\mathrm{Zn} / \mathrm{Cd}$ hyperaccumulator Thlaspi caerulescens. Proceedings of the National Academy of Sciences of the United States of America. 97, 4956-4960.

Qin, H., Cai, Y., Liu, Z., Wang, G., Wang, J., Guo, Y., Wang, H., 2012. Identification of QTL for zinc and iron concentration in maize kernel and cob. Euphytica. 187, 345-358.

Ramesh, S.A., Choimes, S., Schachtman, D.P., 2004. Over-expression of an Arabidopsis zinc transporter in Hordeum vulgare increases short-term zinc uptake after zinc deprivation and seed zinc content. Plant Molecular Biology. 54, 373-385.

Reid, R.J., Brookes, J.D., Tester, M.A., Smith, F.A., 1996. The mechanism of zinc uptake in plants. Planta. 198, 39-45.

Rengel, Z., 1995. Carbonic anhydrase activity in leaves of wheat genotypes differing in $\mathrm{Zn}$ efficiency. Journal of Plant Physiology. 147, 251-256.

Rengel, Z., 2001. Genotypic differences in micronutrient use efficiency in crops. Communications in Soil Science and Plant Analysis. 32, 1163-1186.

Rengel, Z., Graham, R.D., 1995a. Importance of seed $\mathrm{Zn}$ content for wheat growth on Zn-deficient soil. II. Grain yield. Plant and Soil. 173, 267-274. 
Rengel, Z., Graham, R.D., 1995b. Wheat genotypes differ in zinc efficiency when grown in the chelatebuffered nutrient solution. I. Growth. Plant and Soil. 176, 307-316.

Rengel, Z., Romheld, V., Marschner, H., 1998. Uptake of zinc and iron by wheat genotypes differing in tolerance to zinc deficiency. Journal of Plant Physiology. 152, 433-438.

Rengel, Z., Wheal, M.S., 1997. Kinetic parameters of zinc uptake by wheat are affected by the herbicide chlorsulfuron. Journal of Experimental Botany. 48, 935-941.

Ribaut, J.M., William, H.M., Khairallah, M., Worland, A.J., Hoisington, D., 2001. Genetic Basis of Physiological Traits. In: Reynolds, M.P., OrtizMonasterio, J.I., McNab, A. (Eds.), Application of Physiology in Wheat Breeding. D.F. CIMMYT, pp. 29-47, Mexico, pp. 29-47.

Romagosa, I., Han, F., Ullrich, S.E., Hayes, P.M., Wesenberg, D.M., 1999. Verification of yield QTL through realized molecular marker-assisted selection responses in barley cross. Molecular Breeding. 5, 143-152.

Römheld, V., Marschner, H., 1991. Function of micronutrients in plants. In: Mortvedt, J.J., Cox, F.R., Shuman, L.M., Welch, R.M. (Eds.), Micronutrients in Agriculture. Soil Science Society of America, Book Series No. 4, pp. $297-$ 328, Madison, USA, pp. 297-328.

Sadeghzadeh, B., 2008. Mapping of chromosome regions associated with seed $\mathrm{Zn}$ accumulation in barley, $\mathrm{PhD}$ thesis. Faculty of Natural and Agricultural Sciences. The University of Western Australia, Perth.

Sadeghzadeh, B., Rengel, Z., Li, C., 2013. Quantitative trait loci (QTL) of seed $\mathrm{Zn}$ accumulation in barley population Clipper x Sahara. Journal of Plant Nutrition. Under Press.
Sadeghzadeh, B., Rengel, Z., Li, C.D., 2009. Molecular marker linked to a chromosome region regulating seed $\mathrm{Zn}$ accumulation in barley. Molecular Breeding. (In Press).

Sattelmacher, B., 2001. The apoplast and its significance for plant mineral nutrition. New Phytologist. 149, 167-192.

Schwartz, S.M., Welch, R.M., Grunes, D.L., Cary, E.E., Norvell, W.A., Gilbert, M.D., Meridith, M.P., Sauchirico, C.A., 1987. Effect of zinc, phosphorus and root-zone temprature on nutrient uptake by barley. Soil Science Society of America Journal. 51, 371-375.

Septiningsih, E.M., Trijatmiko, K.R., Moeljopawiro, S., McCouch, S.R., 2003. Identification of quantitative trait loci for grain quality in an advanced backcross population derived from the Oryza sativa variety IR64 and the wild relative O. rufipogon. Theoretical and Applied Genetics. 107, 1433-1441.

Sillanpää, M., 1990. Micronutrient assessment at the country level: an international study. FAO Soils Bulletin No. 63. Food and Agriculture Organisation of the United Nations, Rome.

Singh, B., Natesan, S.K.A., Singh, B.K., Usha, K., 2005. Improving zinc efficiency of cereals under zinc deficiency. Current Science. 88, 36-44.

Singh, S.P., Westermann, D.T., 2002. A single dominant gene controlling resistance to soil zinc deficiency in common bean. Crop Science. 42, 1071-1074.

Streeter, T.C., Rengel, Z., Neate, S.M., Graham, R.D., 2001. Zinc fertilisation increases tolerance to Rhizoctonia solani (AG 8) in Medicago truncatula. Plant and Soil. 228, 233-242.

Uauy, C., Distelfeld, A., Fahima, T., Blechl, A., Dubcovsky, J., 2006. A NAC gene regulating senescence, improves grain protein, zinc, and iron content in wheat. Science. 314, 1298-1301. 
Van der Zaal, B.J., Neuteboom, L.W., Pinas, J.E., Chardonnens, A.N., Schat, H., Verkleij, J.A.C., Hooykaas, P.J.J., 1999. Overexpression of a novel Arabidopsis gene related to putative zinc transporter genes from animals can lead to enhanced zinc resistance and accumulation. Plant physiology. 119, 1047-1055.

Vreugdenhil, D., Aarts, M.G.M., Koornneef, M., Nelissen, H., Ernst, W.H.O., 2004. Natural variation and QTL analysis for cationic mineral content in seeds of Arabidopsis thaliana. Plant, Cell \& Environment. 27, 828-839.

Wang, P., Bi, S., Ma, L., Han, W., 2006. Aluminum tolerance of two wheat cultivars (Brevor and Atlas66) in relation to their rhizosphere $\mathrm{pH}$ and organic acids exuded from roots. Journal of Agricultural and Food Chemistry. 54, 10033-10039.

Welch, R.M., 1995. Micronutrient nutrition of plants. Critical Reviews in Plant Sciences. 14, 49-82.

Welch, R.M., Graham, R.D., 2002. Breeding crops for enhanced micronutrien content. Plant and Soil. 245, 205-214.

Welch, R.M., Graham, R.D., 2004. Breeding for micronutrients in staple food crops from a human nutrition perspective. Journal of Experimental Botany. 55, 353-364.
White, P.J., Whiting, S.N., Baker, A.J.M., Broadley, M.R., 2002. Does zinc move apoplastically to the xylem in roots of Thlaspi caerulescens? New Phytologist. 153, 201-207.

WHO, 2002. The World Health Report 2002; Reducing Risks, Promoting Healthy Life. World Health Organization, pp. 1-168, Geneva, Switzerland.

Xu, Y., An, D., Liu, D., Zhang, A., Xu, H., Li, B., 2012. Molecular mapping of QTLs for grain zinc, iron and protein concentration of wheat across two environments. Field Crops Research. 138, 57-62.

Yang, X., Tian, X., Lu, X., Cao, Y., Chen, Z., 2011. Impacts of phosphorus and zinc levels on phosphorus and zinc nutrition and phytic acid concentration in wheat (Triticum aestivum L.). Journal of the Science of Food and Agriculture. 91, 2322-2328.

Zhang, F.S., Römheld, V., Marschner, H., 1991. Diurnal rhythm of release of phytosiderophores and uptake rate of zinc in iron-deficient wheat. Soil Science and Plant Nutrition. 37, 671-678. 